\title{
Bacteriological quality of drinking water in the Atebubu-Amantin District of the Brong-Ahafo Region of Ghana
}

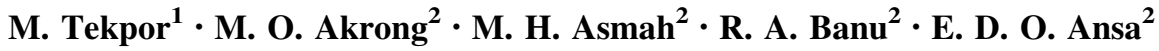

Received: 27 August 2015/Accepted: 1 August 2016/Published online: 8 August 2016

(c) The Author(s) 2016. This article is published with open access at Springerlink.com

\begin{abstract}
The study was carried out to determine the bacteriological safety of water in hand-dug wells in the Atebubu-Amantin District of the Brong-Ahafo Region in Ghana. A total of 60 samples were collected from ten hand dug wells and analysed for total coliform (TC), faecal coliform (FC), E. coli (EC), Salmonella spp. (SP) and Enterococcus spp. (ES). Data was collected in both the rainy and the dry seasons. The results obtained showed that water from all the wells in the study area did not meet the World Health Organisation guideline and Ghana standard for drinking water of zero (0) coliform forming unit (cfu) per $100 \mathrm{ml}$ for TC, FC, EC, SP and ES, respectively. Contamination was found to be high in the wells during the wet season as compared to the dry season. Wells (A1 to A5) which were close to septic tanks had high bacteria counts in both seasons. The total coliform counts ranged from 2.98 to $5.93 \log \mathrm{cfu} / 100 \mathrm{ml}$ in the wet season and $3.10-5.03 \log \mathrm{cfu} / 100 \mathrm{ml}$ in the dry season. There was drastic reduction of faecal coliform count from a range of $2.78-4.55 \mathrm{log} \mathrm{cfu} / 100 \mathrm{ml}$ in the wet season to $1.70-3.51 \log \mathrm{cfu} / 100 \mathrm{ml}$ in the dry season. The high bacteria count in wells A1 to A5 could be attributed to the closeness of the wells to the septic tank, and contaminant transport through the saturated underground zones. It is recommended that the water should be treated properly before drinking.
\end{abstract}

M. O. Akrong

markosaakrong@gmail.com

1 Kwame Nkrumah University of Science and Technology, Kumasi, Ghana

2 Environmental Biology and Health Division of CSIR, Water Research Institute, Accra, Ghana
Keywords Septic tank - Water borne diseases · Hand-dug well $\cdot$ Water quality and seasonal

\section{Introduction}

The availability and accessibility of clean freshwater is the key to sustainable development and poverty reduction. Access to safe drinking water is a fundamental human right; however, it remains inaccessible to about 1.1 billion people in the world. The situation is worse in developing countries where the population growth has outstripped the ability of governments to provide public infrastructure for the effective management of waste and water supply. According to the World Health Organisation (WHO), a large proportion of the population in developing countries live in rural and suburban areas where conventionally treated drinking water is generally unavailable (WHO 1998). The consumption of unsafe water jeopardizes both the physical and social health of people. It is estimated that the hourly mortality rate of children under the age of 5 years consuming contaminated drinking water is 400 deaths (Gadgil 1998). Human water needs in most developing countries are usually met by water obtained from rainfall, streams, wells, boreholes and pipe-borne water depending on the locality and the technology available.

In many African communities, hand-dug wells have become a major means of obtaining domestic water (Cronin et al. 2007). Hand-dug wells are relatively cheap to construct and maintain (Water Aid 2013) but they are often at risk of contamination due to a number of factors, including inflow from surface runoff, contamination as water is abstracted by users, and/or contaminant transport through the unsaturated and saturated zones (OkottoOkotto et al. 2015). It is estimated that in the developing 
world, $80 \%$ of all diseases are directly related to poor drinking water and insanitary conditions (UNESCO 2006). In Ghana, $23.6 \%$ of Ghanaians rely on unimproved sources of water (Ghana Statistical Service 2013). Of this 23.6, $10 \%$ rely on unimproved or hand dug wells for water. These hand dug wells pose a major risk to public health and contribute to the spread of diseases such as guinea worm, typhoid, cholera, hepatitis A, and other diarrhoeal-related diseases.

According to the 2010 census report of Ghana, $31.7 \%$ of the rural population of the Brong-Ahafo Region of Ghana still depends on the unimproved water sources (Ghana Statistical Service 2012). These unimproved water sources are mainly dominated by unimproved hand-dug wells in the Atebubu-Amantin District of the Brong-Ahafo Region. High prevalence rates of water-borne diseases had been reported by the district health directorate of AtebubuAmantin from 2009 to 2015. This study was therefore conducted to determine the safety of water in hand-dug wells in the Atebubu-Amantin District of the Brong-Ahafo Region and to explore the factors influencing water quality.

\section{Materials and methods}

\section{Study area and sampling}

The Atebubu-Amantin District of the Brong-Ahafo Region lies approximately between latitudes $0^{\circ} 23^{\circ} \mathrm{N}$ and longitudes $0^{\circ} 30^{\circ} \mathrm{W}$ and $1^{\circ} 26^{\circ} \mathrm{W}$. The district has a total land area of $3990 \mathrm{~km}^{2}$ with a population of 84,000 (Ghana Statistical Service 2012).

The district lies in the transitional zone between the forest and savannah zones. The district has two seasons; the dry season (November-May) and the wet season which occurs from May to October each year. Although different sources of water (such as rivers, streams, boreholes and hand dug wells) exist in the district, the most dominant source of water for household use comes from hand dug wells. The sanitary conditions of some of the hand dug wells are poor as animals roam and defecate around some of the wells.

\section{Sample collection and analysis}

Water samples were collected from hand dug wells in the Atebubu-Amantin District. Wells were selected based on their use. Preference was given to the wells that served as a source of drinking water as well as for other domestic activities. To determine the temporal variations in water quality, sampling was conducted in the wet season (September-November) and the dry season (from December-February).
A total of six samples were collected from each of the ten sampling sites designated as A1, A2, A3, A4, A5, A6, A7, A8, A9 and A10 (see Fig. 1b). The sampling sites were chosen with respect to their distance from septic tank. The six samples were made up of three samples for each of the two seasons. The samples were collected in $500 \mathrm{ml}$ sterile sampling bottles. All water samples were kept in a cool box containing ice packs and immediately transported to the laboratory for analysis. The microbiological parameters were analyzed in the laboratory as follows: Total Coliforms (TC), Faecal Coliforms (FC), E. coli, Salmonella and Enterococcus. These bacterial examinations in the water samples were carried out using the membrane filtration method as prescribed in the Standard Methods for the Examination of Water and Wastewater (APHA-AWWAWEF 1998). Analytical results were expressed in colony forming unit (cfu) per $100 \mathrm{ml}$.

\section{Statistical analysis}

All statistical analysis and transformations were carried out using SPSS version 16 for windows. The bacterial counts obtained were normalized by $\log$ transformation. $T$-test at $5 \%$ significant level was carried to compare means between the wet and dry seasons. Correlation analysis was also carried out to investigate any possible relationship between distances from sanitary facilities, well depth and bacteriological count.

\section{Results and discussion}

The results of bacteriological analysis of wells in Atebubu showed contamination with total coliform, faecal coliform, E. coli, Salmonella spp., and Enterococcus spp. The bacterial colony counts were all above the WHO guideline and Standard limit of zero (0) cfu/ $100 \mathrm{ml}$ for drinking purposes. In general, seasonal changes showed significantly higher bacteriological count in the wet season than in the dry season (Table 1; Figs. 2, 3). This result indicates a higher risk of waterborne diseases in the wet season and this is consistent with similar studies carried out on hand dug wells (Anim et al. 2010; Akple et al. 2011). Odeyemi et al. (2011) noted that faecal contamination of wells in Oke-Osun in Nigeria was as a result of faeces and other wastes from anthropogenic sources located in bushes close to the well. This was eventually washed by rain water as runoff into the spring. Similar observations of farm animal droppings littered around the openings of wells made in Atebubu. The transport of bare soil contaminated with faeces by wind into open wells as well as surface runoff could also have accounted for the high bacterial load 
$\mathbf{A}$

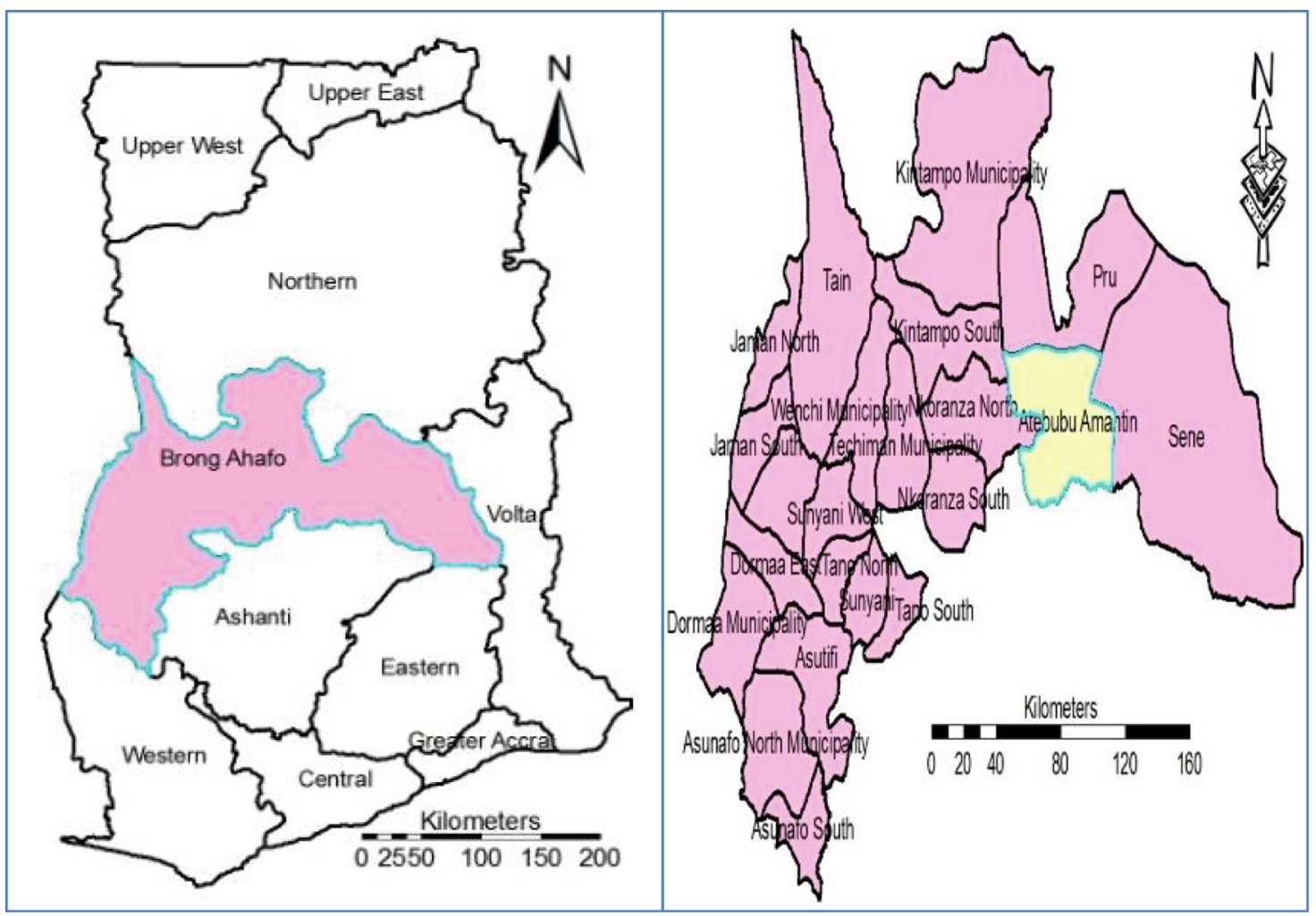

B

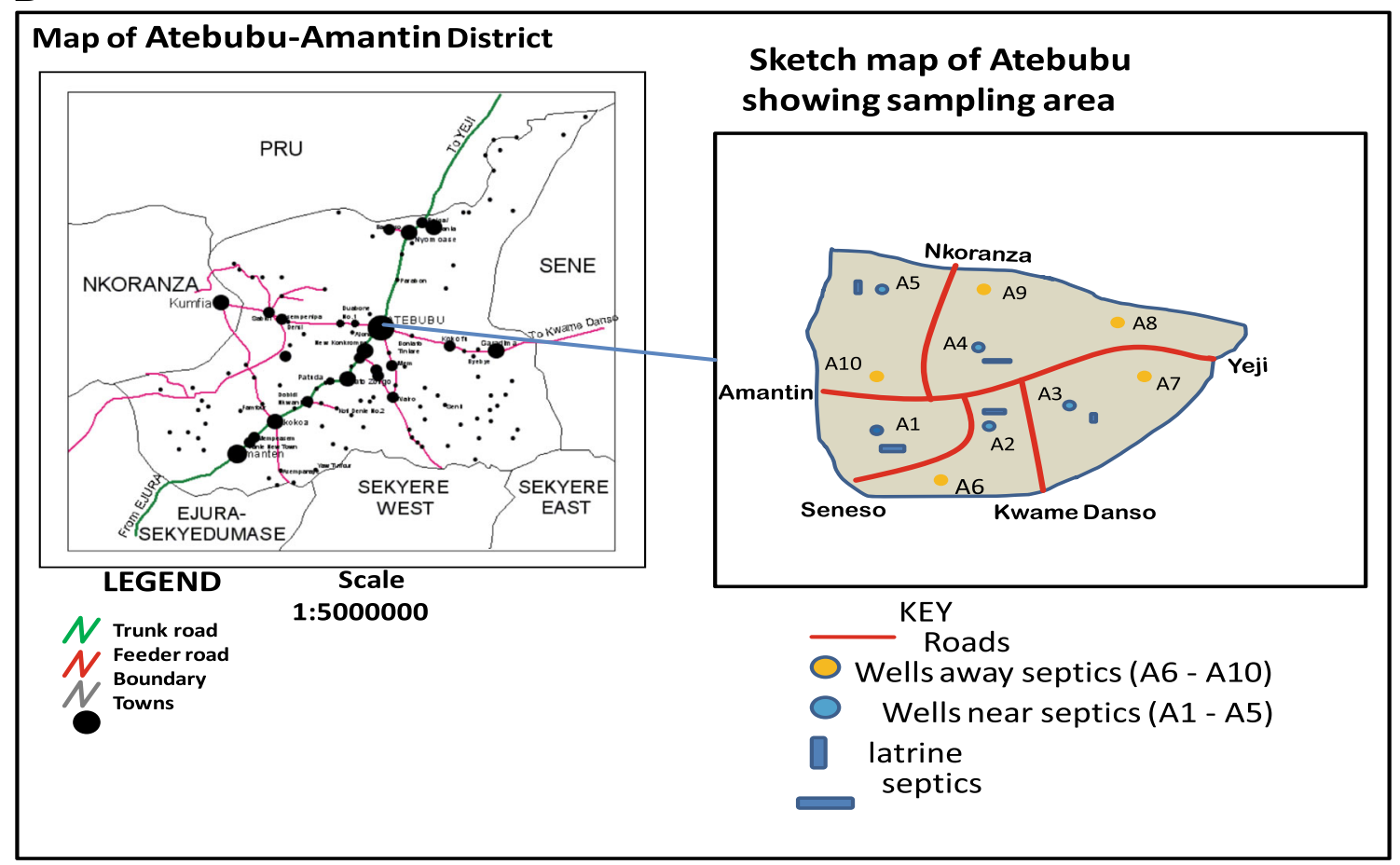

Fig. 1 a Map of Ghana and the Brong-Ahafo Region showing the Atebubu-Amantin District. b Map of the Atebubu-Amantin District showing the sampling sites 
Table 1 Summary of bacteriological data collected in the Atebubu-Amantin District

\begin{tabular}{|c|c|c|c|c|c|c|c|c|}
\hline \multirow[t]{2}{*}{$\begin{array}{l}\text { Sampling } \\
\text { sites }\end{array}$} & \multicolumn{2}{|c|}{$\begin{array}{l}\text { Total coliforms }(\log \\
\text { cfu/100 ml) }\end{array}$} & \multicolumn{2}{|c|}{$\begin{array}{l}\text { Faecal coliforms (log } \\
\text { cfu/100 ml) }\end{array}$} & \multicolumn{2}{|c|}{$\begin{array}{l}\text { Salmonella sp. (log } \\
\text { cfu/100 ml) }\end{array}$} & \multirow[t]{2}{*}{$\begin{array}{l}\text { Depth } \\
\text { (m) }\end{array}$} & \multirow[t]{2}{*}{$\begin{array}{l}\text { Distance } \\
(\mathrm{m})\end{array}$} \\
\hline & $\begin{array}{l}\text { Rainy } \\
\text { season }\end{array}$ & $\begin{array}{l}\text { Dry } \\
\text { season }\end{array}$ & $\begin{array}{l}\text { Rainy } \\
\text { season }\end{array}$ & $\begin{array}{l}\text { Dry } \\
\text { season }\end{array}$ & $\begin{array}{l}\text { Rainy } \\
\text { season }\end{array}$ & $\begin{array}{l}\text { Dry } \\
\text { season }\end{array}$ & & \\
\hline A1 & 5.82 & 4.96 & 4.01 & 2.90 & 1.65 & 1.62 & 3.5 & 9.2 \\
\hline A2 & 6.02 & 4.69 & 4.65 & 2.99 & 2.11 & 1.63 & 3.0 & 8.0 \\
\hline A3 & 5.39 & 4.17 & 3.88 & 2.96 & 1.85 & 1.68 & 3.8 & 7.3 \\
\hline A4 & 4.82 & 4.18 & 3.66 & 2.90 & 2.09 & 1.57 & 3.6 & 17.3 \\
\hline A5 & 5.82 & 4.94 & 3.75 & 2.97 & 2.10 & 1.23 & 4.3 & 12.4 \\
\hline A6 & 3.08 & 3.43 & 2.85 & 1.72 & 1.33 & 1.35 & 6.0 & $>90$ \\
\hline A7 & 3.90 & 3.42 & 3.06 & 2.61 & 1.62 & 1.31 & 5.0 & $>90$ \\
\hline A8 & 3.76 & 3.20 & 2.93 & 2.23 & 1.48 & 1.27 & 3.5 & $>90$ \\
\hline A9 & 3.70 & 3.51 & 3.03 & 2.54 & 1.60 & 1.06 & 6.0 & $>90$ \\
\hline A10 & 3.98 & 3.43 & 3.03 & 2.49 & 1.80 & 1.50 & 7.4 & $>90$ \\
\hline
\end{tabular}

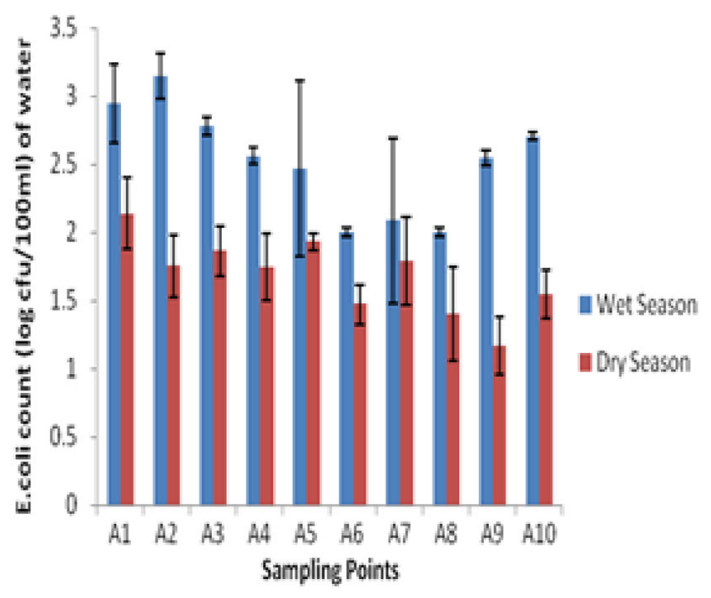

Fig. 2 Seasonal variation of E. coli in hand dug wells

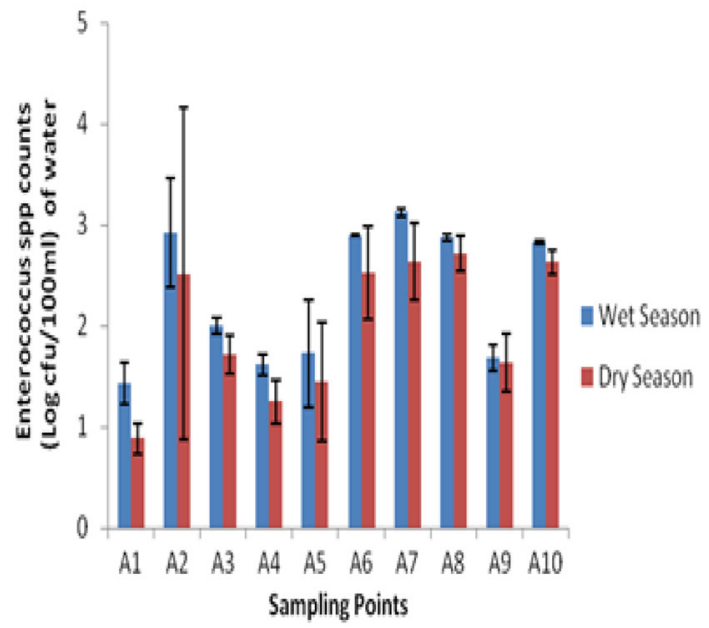

Fig. 3 Seasonal variation of Enterococcus sp. in hand dug wells observed during the wet season as compared to the dry season.

Guidelines for engineers, stress the need to 'protect' groundwater sources from subsequent contamination with sanitary seals, caps, aprons and spillways around wells and bore-holes, and carefully constructed spring boxes, diversion ditches and fences around springs (Cairncross and Feachem 1993; Davis and Lambert 2002). However, most of the hand dug wells in Atebubu were constructed by untrained individuals in the community; consequently most of the wells in the district do not have any protective caps and spillways. In addition to the lack of seals or caps and spillways around the wells, the people responsible for the construction of the wells may have contaminated the wells prior to its completion. Because these people are untrained hands, standards or best practices for construction of the wells are not followed. This could partly account for the high bacterial contamination recorded in the wells in the district.

The citing of wells close to septic tanks poses a risk of contamination of groundwater when these tanks leak. Analysis of the relationship between bacterial contamination and distance from sanitary facilities showed that as the distance from septic tanks increased, the bacterial contamination of the wells decreased (Table 2). Total coliform count in the wells showed a strong negative correlation with distance from sanitary facilities. The correlation coefficient, $r$ recorded for TC during the rainy season was -0.93 and that for the dry season was $r=-0.92$. Shittu et al. (2008) recorded a stronger negative correlation in the wet season than in the dry season when they examined total coliforms in wells close to septic tanks and latrines. The correlations recorded for both seasons in this study was very similar. This suggests that the source of TC loadings in the hand dug wells may not be directly influenced by 
Table 2 Pearson's correlation matrix showing the relationships between variables measured

\begin{tabular}{lcccccc}
\hline & Depth & Distance & E. coli & Enterococcus & FC & Salmonella \\
\hline Depth & 1 & & & & & \\
Distance & 0.71 & 1 & 1 & & & \\
E. coli & -0.22 & -0.44 & -0.01 & 1 & & \\
Enterococcus & 0.40 & 0.69 & 0.85 & -0.13 & & \\
FC & -0.47 & -0.64 & 0.75 & -0.06 & 0.77 & 1 \\
Salmonella & -0.32 & -0.55 & 0.70 & -0.45 & 0.85 & 0.70 \\
TC & -0.58 & -0.85 & & & \\
\hline
\end{tabular}

seasonal variability. The faecal coliform count and the distance of the well from sanitary facilities showed an inverse relationship $(r=-0.47)$. Adeyemi et al. (2004) have also reported a reduction in faecal coliforms in dug wells with increasing distance from sources of pollution which validates the findings of this study.

The correlation between the levels of Enterococcus in the wells and the distance from the sanitary facilities showed a strong positive correlation $(r=0.69)$. The positive correlation between Enterococcus count and the distance from the sanitary facilities could be explained by the argument that, the Enterococcus present in the wells did not emanate from the sanitary facilities but from other sources which could possibly include the containers used in fetching water from the wells. The use of improved vessels alone has been shown to decrease microbiological contamination and diarrhoeal diseases (Roberts et al. 2001).

A negative correlation $(r=-0.44)$ was obtained between the levels of $E$. coli and the distance of well from sanitary facilities. E. coli is a part of the faecal coliform group of bacteria that emanate from faecal material from humans and other warm-blooded animals. The correlation coefficient of -0.44 observed, suggests some amount of faecal contamination and infiltration into ground water. This is made possible by the high water table and the closeness of sanitary facilities to these wells.

Numerous studies have reported on the microbial contamination of shallow ground water and the transport of coliform bacteria within the saturated subsurface environment (Hadgedorn et al. 1981). Analysis of the relationship between bacterial count and the depth of the wells depicted a negative correlation for total coliform, faecal coliform, Salmonella, and E. coli (Table 2). These observations showed that, as the depth of the water decreases (especially in cases where the water table is high), the propensity for contamination is high. This result is corroborated by Reay (2004) who conducted a study to determine the impact of septic tanks on ground water quality and near-shore sediment flux. In his study, he noted that septic tanks contribute to nonpoint source pollution through the direct introduction of contaminants such as pathogenic bacteria, nutrients, and organic matter. The results of his study also showed that the shallow water table depths and the permeable sandy substrates of his study sites were typical of many coastal plain settings and represent a high-risk setting for ground water contamination from domestic waste water disposal (Reay 2004). The Atebubu district cannot be described as a coastal plain, but the area has a high water table and the probability for pathogenic bacteria to be transmitted within the saturated subsurface environment is high.

\section{Conclusion}

Hand-dug wells in Atebubu were found to be grossly polluted and unsafe for drinking. All bacteriological parameters analysed were above the WHO guideline and Standards Authority's limit for drinking water. Bacteriological counts recorded showed a seasonal pattern where counts were elevated in the wet season compared to the dry season. The high bacterial count in the wet season could be attributed to the transport of contaminated soil into the unprotected open wells by winds preceding rainfall and also surface runoff. The depth of the water in the wells-which represents to some degree the height of the water table-was found to be correlated to the bacterial loading of the wells. A negative correlation was established between the bacterial counts and the depth as well as its distance from septic tanks. It is recommended that the water from the wells are treated before use.

Open Access This article is distributed under the terms of the Creative Commons Attribution 4.0 International License (http:// creativecommons.org/licenses/by/4.0/), which permits unrestricted use, distribution, and reproduction in any medium, provided you give appropriate credit to the original author(s) and the source, provide a link to the Creative Commons license, and indicate if changes were made.

\section{References}

Adeyemi O, Odeyede OB, Oladiji AT (2004) Physico chemical and microbial characteristics of leachates of hand-dug well water 
contamination. A case study in Ojota-Lagos, Nigeria. J Health Popul Nutr 3:351-358

Akple M, Keraita B, Konradsen F, Agbenowu E (2011) Microbiological quality of water from hand-dug wells used for domestic purposes in urban communities in Kumasi, Ghana. Urban Water J 8(1):57-64

Anim F, Nyame FK, Armah TK (2010) Coliform status of water bodies from two districts in Ghana. Implication for rural water resource management, West Africa

APHA-AWWA-WEF (1998) Standard methods for the examination of water and wastewater, 20th edn. American Water Works Association, USA

Cairncross S, Feachem R (1993) Environmental health in the tropics. Wiley, Chichester

Cronin A, Hoadley A, Gibson J, Breslin N, KouontoKomou F, Haldin L, Pedley S (2007) Urbanisation effects on groundwater chemical quality: findings focusing on the nitrate problem from 2 African cities reliant on on-site sanitation. J Water Health $5: 441-454$

Davis J, Lambert R (2002) Engineering in emergencies, 2nd edn. Intermediate Technologies Ltd, London

Gadgil A (1998) Drinking water in developing countries. Annu Rev Energy Env 23:253-286

Ghana Statistical Service (2012) Population and housing census 2010. Summary report of final results. Ghana Statistical Service, Accra

Ghana Statistical Service (2013) 2010 population and housing census report. Millennium development goals in Ghana. Ghana Statistical Service, Accra
Hadgedorn C, McCoy EL, Rahe TM (1981) The potential for ground water contamination from septic effluents. J Environ Qual $10(1): 1-8$

Odeyemi AT, Akinjogunla OJ, Ojo MA (2011) Bacteriological, physicochemical and mineral studies of water samples from Artesian bore-hole, spring and hand dug well located at OkeOsun, Ikere-Ekiti, Nigeria. Arch Appl Sci Res 3(3):94-108

Okotto-Okotto J, Okotto L, Price H, Pedley S, Wright J (2015) A longitudinal study of long-term change in contamination hazards and shallow well quality in two neighbourhoods of Kisumu, Kenya. Int J Environ Res Public Health 12(4):4275-4291

Reay WG (2004) Septic tank impacts on ground water quality and nearshore sediment nutrient flux. Ground Water 42(7):1079-1089

Roberts L, Chartier Y, Chartier O, Malenga G, Toole M, Rodka H (2001) Keeping clean water clean in a Malawi refugee camp: a randomised intervention trial. Bull World Health Organ 79:280-287

Shittu OB, Olaiton JO, Amusa TS (2008) Physico-chemical and bacteriological analysis of water used for drinking and swimming purposes in Abeokuta, Nigeria. Afr J Biomed Res 11:285-290

UNESCO (2006) Water-related diseases. UNESCO water portal newsletter no. 161. http://www.unesco.org/water/news/ newsletter/161.shtml. Accessed 13 June 2015

Water Aid (2013) Hand-Dug Wells. Technical Brief, London. http:// www.wateraid.org/technologies. Accessed 15 July 2015

WHO (1998) Guidelines for drinking water quality. Health criteria and other supporting information, 2nd edn. World Health Organization, Geneva 